\title{
PANDEMI COVID-19 SEBAGAI ALASAN IMPEACMENT PRESIDEN PRESPEKTIF HUKUM TATA NEGARA
}

\author{
Muchlisin \\ Universitas Islam Negeri Sunan Ampel Surabaya \\ muchlisin.alfarabi@gmail.com
}

\begin{abstract}
In the development of carrying trust as head of state as well as head of government, a president must execute the mandate that is contained in the law. This research was conducted to see the foundation used in the presidential impeachment, as well as whether the Covid-19 pandemic could be a reason for the president's impeachment. The author finds that there are several reasons for the impeachment in Indonesia, which is appropriate in security - Constitution 1945 Article 7A fourth amendment. States that the President and Vice-Presidents may be dismissed during his tenure by the MPR on the proposal of the DPR. In this case, of course, if it is proven to commit a violation of the law in the form of a blasphemy against the state, corruption, bribery, or other serious criminal acts.
\end{abstract}

Keywords: impeachment.pandemic covid-19

\section{Pendahuluan}

Indonesia memiliki seorang kepala negara yang sekaligus berperan menjadi kepala pemerintahan yaitu seorang presiden. Di negara Indonesia Sistem pemerintahan tersebut lazim disebut dengan sistem pemerintahan Presidensial. Seorang presiden memiliki kekuasaan yang 
terbilang cukup besar. Meskipun begitu seorang presiden tidak serta merta dalam menjalankan tugasnya. Presiden di dalam menjalankan tugasnya, ketika terjadi kesalahan yang hal itu melanggar konstitusi atau undang-undang, maka presiden dapat diberhentikan.

Adapun undang-undang di Indonesia yaitu UUD 1945 sebelum Amandemen menyatakan pemberhentian Presiden dan/atau wakil Presiden dapat dengan alasan-alasan yang dalam hal ini bersifat politik bukan bersifat yuridis. Alasan tersebut tidak lazim digunakan atupun diterapkan di dalam sebuah negara yang memakai sistem pemerintahan presidensial. ${ }^{1}$ Maka dari itu dalam Amandemen keempat UUD 1945 terdapat ketentuan pemberhentian Presiden dan/atau wakil presiden di dalam masa jabatan yang sedang berlangsung dan berdasarkan pada beberapa alasan yang bersifat yuridis, serta berlandaskan pada ketentuan normatif limitatif yang telah disebutkan di dalam konstitusi.

Di dalam pemberhentian presiden dan/atau wakil presiden tersebut dapat dilakukan dengan sebelumnya sudah melalui adanya proses konstitusional di Mahkamah Konstitusi (MK). Mahkamah Konstitusi yang akan melakukan pemeriksaan, mengadili, serta memutus pendapat DPR yang berkaitan dengan pelanggaran hukum yang dilakukan oleh Presiden dan/atau wakil Presiden. Berupa penghianatan terhadap negara, korupsi, penyuapan, tindak pidana berat lain ataupun sudah tidak memenuhi syarat sebagai Presiden dan/atau wakil presiden. Pemberhentian Presiden dan/atau wakil Presiden di dalam masa jabatannya oleh MPR dengan didahului usul dari DPR tersebut secara teknis dalam Hukum Tata Negara disebut Impeachment.

Proses Impeachment di dalam konstitusi masih menjadi problematika karena tiadanya ketentuan-ketentuan untuk mengatur lebih jauh persoalan teknis di dalam proses Impeachment. Sehingga masih perlu diupayakan formulasi yang tepat terhadap proses Impeachment. Serta terdapat peraturan hukum yang jelas terhadap persoalan Impeachment seorang Presiden.

Sesungguhnya dalam proses Impeachment merupakan bentuk instrument untuk mencegah terjadinya penyalahgunaan kekuasaan atau abuse of power dari pemegang kekuasaan. ${ }^{2}$ Hal ini mengacu pada konstitusi yang telah digagas pada tahun 1787 di Philadelphia, Pennsylvania, yang merupakan para bapak bangsa Amerika Serikat yang melihat adanya sebuah kecenderungan para pemimpin menjadi pribadi yang korup ketika berkuasa. Selain korup, para pemimpin itu juga

\footnotetext{
${ }^{1}$ Jimly Asshiddiqie, Gagasan Kedaulatan Rakyat Dalam Konstitusi dan pelaksanaannya di Indonesia (Jakarta: PT. Ichtiar Baru Van Hoeve, 1994), 73.

2 Ibid, 74.
} 
berusaha untuk terus berkuasa selama mungkin. Oleh karena itu, mereka menciptakan sebuah konstitusi yang didasarkan pada fondasi checks and balances yang dapat meminimalisasir penyalahgunaan kekuasaan.

Impeachment hadir sebagai instrument dalam upaya menegur perbuatan menyimpang oleh penguasa, penyalahgunaan dan pelanggaran terhadap kepercayaan publik dari orang yang mempunyai jabatan publik. $^{3}$ Impeachment diartikan sebagai suatu proses peradilan pidana terhadap seorang pejabat publik yang dilaksanakan di hadapan Senat, disebut dengan istilah quasi political court. Suatu proses Impeachment dimulai dengan adanya articles of impeachment, yang berfungsi sama dengan surat dakwaan dari suatu peradilan pidana. ${ }^{4}$ Oleh karena itu Impeachment adalah satu surat resmi yang berisi tuduhan yang menyebabkan dimulainya suatu proses Impeachment. Hanya saja menurut sejarahnya, Impeachment tidak mudah digunakan dan tingkat keberhasilannya dalam menjatuhkan seorang presiden sangat rendah. ${ }^{5}$

Dalam hal sejarah ketatanegaraan Islam Pada masa Khulafa alRasyidin, terjadi dua kali pemberhentian khalifah secara tidak normal karena pemberontakan serta ketidakpercayaan rakyat terhadap pemimpinnya. Khalifah Utsman Ibn Affan yang mati karena dibunuh oleh ribuan orang yang datang dari Mesir, Kufah, dan Basrah. Hal tersebut terjadi karena Khalifah Usman Ibn Affan dituduh telah melakukan nepotisme, dengan mengangkat beberapa keluarganya menjadi gubernur. Serta dianggap telah melakukan korupsi dengan menggunakan dana Baitul Mal untuk kepentingan pribadinya. ${ }^{6}$ Pembunuhan oleh Abd al-Rahman bin Muljam terhadap khalifah Ali Ibn Thalib yang terjadi pada saat beliau menuju mesjid untuk mengimami sholat subuh disebabkan karena kaum Khawarij yang tidak setuju dengan tahkim (arbitrase) yang dilakukan Muawiyah Ibn Sufyan untuk berdamai. ${ }^{7}$

Di dalam negara Indonesia persoalan-persolan yang berkaitan dengan Impeachment tersebut masih memerlukan beberapa penelitian yang lebih mendalam. khususnya terfokus dalam berkaitan dengan, apakah proses Impeachment tunduk pada prinsip-prinsip dan asas-asas yang terdapat di dalam hukum pidana dan hukum acara pidana. Serta alasan

\footnotetext{
${ }^{3}$ Abdul Rahman, Universitas Islam Negeri (UIN) Alauddin Makassar IMPEACHMENT DALAM UUD 1945 PASCA AMANDEMEN (Analisis Terbadap Proses Hukum Vis-a-Vis Proses Politik).

${ }^{4}$ Ibid.

${ }^{5}$ Jimly Asshiddiqie, 67.

6 J. Suyuthi Pulungan, Fiqh Siyasah, Ajaran, Sejarah, dan Pemikiran Edisi I (Cet. V; Jakarta: Rajawali Pers, 2005), h 148-151.

${ }^{7}$ Ibid., 158.
} 
yang dapat diberlakukannya suatu Impeachment terhadap Presiden. Penulis dalam hal ini lebih terfokus pada fakor-faktor yang dapat dijadikan alasan penjatuhan Impeachment Presiden. Sesuai dengan judul penelitian penulis apakah faktor adanya Pandemi Covid-19 ini dapat dijadikan salah satu alasan penjatuhan Impeachment Presiden.

\section{Metode Penelitian}

Metode penelitian riset ini adalah yuridis normatif dengan menganalisis ketentuan mengenai Impeachment di Negara Indonesia. peraturan Mahkamah Konstitusi Indonesia serta peraturan nasional lain yang terkait. Negara Indonesia dipilih karena bertujuan untuk memahami fenomena yang terjadi belakangan ini di Negara Tersebut. Hal ini dimaksudkan untuk mencari pengaruh pandemi covid-19 sebagai alasan Impeachment di negara tersebut.

Jenis riset ini adalah qualitative research yang mengutamakan data sekunder yaitu berupa peraturan perundang-undangan serta literatur lain yang membahas mengenai mekanisme impeachment di Indonesia. Pendekatan penelitian yang digunakan adalah historical approach dan statute approach. Historical approach digunakan agar dapat melihat bagaimana perjalanan sebuah negara terutama Indonesia dalam menemukan mekanisme yang tepat untuk proses pemberhentian pemimpin kekuasaan eksekutifnya. Sedangkan statute approach digunakan sebagai landasan hukum yang otentik mengenai penggunaan sebuah sistem pemerintahan dan mekanisme impeachment baik di Indonesia, khususnya konstitusi suatu negara.

\section{Impeachment di Indonesia}

Sistem Pemerintahan di Indonesia

Teori sistem pemerintahan yang dikembangkan para ahli terdapat sistem semi presidensial yang memadukan ciri antara sistem presidensial dengan sistem parlementer. Terdapat pendapat dari Robert Elgiet bahwa, dua bentuk dari sistem semi presidensial yaitu sistem president parlia mentarism dan premier-parliamentary. ${ }^{8}$ Secara garis besar, yang menjadi perbedaan dari sistem presidensial dan parlementer terletak pada keterkaitan dan keterpisahan antara lembaga legislatif dan lembaga eksekutif. Dalam sistem presidensial, pemilihan presiden dan legislatif dilakukan secara terpisah, sehingga sumber legitimasi keduanya terpisah. Sementara dalam sistem parlementer, sumber legitimasi dari eksekutif adalah legislatif. Dimana pemerintahan yang terbentuk memungkinkan bukan dari partai pemenang pemilihan umum, terutama dalam kondisi

${ }^{8}$ Ibid., Abdul Rahman. 
partai pemenang pemilihan umum tidak mayoritas. Hal ini menyebabkan diharuskannya koalisi antara beberapa partai sehingga sumber legitimasi dari eksekutif bergantung kepada lembaga legislatifnya.

Sistem presidensial yang digunakan di Amerika Serikat (AS) dianggap sebagai contoh penerapan sistem presidensial yang murni. Hal ini disebabkan kriteria utama dari sistem presidensial digunakan di AS yaitu pemilihan presiden langsung oleh rakyat dan masa jabatan pemerintahan yang memiliki waktu yang tetap. ${ }^{9}$ Dua kriteria utama tersebut, menurut Fitra Arsil berkaitan dengan sumber legitimasi dari kekuasaan eksekutif. Pemilihan Presiden secara langsung misalnya, menunjukkan bahwa sumber kekuasaan eksekutif tidak berasal dari kekuasaan legislatif. Sementara masa jabatan yang ditetapkan, menunjukkan bahwa dalam sistem presidensial, eksekutif diganti hanya melalui pemilihan umum. Kedua hal ini menjadikan keduanya tidak mengganggu legitimasi yang lain. ${ }^{10}$

Soehino juga mengemukakan hal yang sama, bahwa di dalam sistem presidensial disebut sebagai sistem yang paling konsekuen di dalam penerapan trias politica yang digagas oleh Montesquieu. Hal ini disebabkan karena dalam sistem ini terdapat pemisahan kekuasaan Negara serta lembaga-lembaga yang memegang pelaksanaan masingmasing kekuasaan Negara dilakukan secara sempurna. Bahkan antara kekuasaan eksekutif dan legislative tidak ada hubungan pertanggungjawaban. Eksekutif dan legislatif masing-masing bertanggungjawab secara langsung kepada rakyat. ${ }^{11}$ Ada sedikitnya 9 (sembilan) prinsip pokok yang perlu dipenuhi oleh suatu sistem pemerintahan agar bisa dikategorikan sebagai sistem presidensial sekaligus membedakannya dengan sistem parlementer.

UUD 1945 sebelum perubahan mengatur mengenai sistem pemerintahan yang menurut RM A.B. Kusuma menjadi kunci pokok pemerintahan di Indonesia yang diantaranya yaitu:

a. Presiden merupakan penyelenggara pemerintahan Negara yang tertinggi dibawah majelis. Oleh karena itu, pemerintahan Negara dipimpin oleh Presiden.

b. Presiden tidak bertanggungjawab kepada DPR. Namun dalam hal persetujuan rancangan undang-undang, Presiden harus menjalankannya bersama dengan DPR. sudah menggunakan sistem pemerintahan presidensial sebelum adanya perubahan UUD 1945. Bahkan sistem ini disepakati untuk tidak

\footnotetext{
${ }^{9}$ Ibd.,

${ }^{10}$ Ibid.,

11 Soehino, Hukum Tata Negara: Sistem Pemerintahan Negara, (Penerbit Liberty: 1993), 81.
} 
diubah sebagaimana disampaikan oleh Amin Aryoso sebagai pimpinan rapat dalam Rapat Panitia Adhoc III Badan Pekerja MPR pada tanggal 12 Oktober 1999.

Berikut beberapa hal yang menjadi kesepakatan Panitia Ad Hoc dalam melakukan pembahasan rancangan Perubahan UUD 1945, yaitu: ${ }^{12}$ a. Pengubahan dilakukan dengan teknik amandemen, sehingga diktum lama yang diubah tetap menjadi bagian dalam naskah UUD 1945 dan diktum baru disisipkan pada dokumen UUD 1945, dengan demikian diktum asli yang telah diubah tetap dapat ditemukan dalam dokumen UUD 1945 yang telah diubah.

b. Pembukaan yang berisi Pancasila sebagai dasar negara tidak dapat diubah.

c. Sistem pemerintahan presidensial dan bentuk negara kesatuan Republik Indonesia tidak menjadi objek amandemen. Keempat, materi penjelasan yang berkualifikasi sebagai norma hukum diangkat menjadi diktum pada bagian batang tubuh.

d. Jika dalam pembahasan tidak tercapai kesepakatan terhadap rancangan diktum maka dikembalikan pada diktum naskah UUD 1945.

Meskipun UUD 1945 yang asli (sebelum amandemen) dipandang menganut sistem presidensial, namun beberapa ahli juga menyatakan bahwa sistem presidensial yang dibangun bukan sistem presidensial murni. Hal tersebut dapat dari ciri-cirinya. Misalnya dalam hal pembuatan undang-undang dilakukan bersama presiden dan DPR sedangkan dalam sistem presidensial Amerika Serikat, undang-undang dibuat oleh kongres, presiden hanya mempunyai hak veto sehingga tidak secara langsung mempengaruhi proses pembentukan undang-undang. ${ }^{13}$

Pengaturan Impeachment di Indonesia

Menurut Jimly impeachment adalah menuntut pertanggungjawaban dalam rangka pengawasan parlemen kepada presiden, apabila presiden melanggar hukum. ${ }^{14}$ Sedangkan pemakzulan berasal dari bahasa Arab yang secara etimologis berarti penyingkiran, pengasingan,

12 Sri Soemantri Martosoewignjo, Konstitusi Indonesia Prosedur dan Sistem Perubahannya Sebelum dan Sesudah UUD 1945, ( Perubahan, Rosdakarya: Bandung, 2016), 202.

13 Kusuma, Sistem Pemerintahan "Pendiri Negara" Versus Sistem Presidensial "Orde Reformasi", (Badan Penerbit Fakultas Hukum Universitas Indonesia: Depok,2011), 17.

14 Jimly Asshiddiqie, Konstitusi dan Konstitusionalisme Indonesia (Jakarta: Mahkamah Konstitusi Republik Indonesia, 2012), 43. 
penyendirian, dan sejenisnya. ${ }^{15}$ Pemakzulan juga berarti meletakan jabatan atau turun tahta raja. ${ }^{16}$ Jimly Asshiddiqie menjelaskan, pemakzulan adalah bahasa serapan dari bahasa Arab yang berarti diturunkan dari jabatan. Atau sama dengan istilah 'impeachment' dalam konstitusi negaranegara Barat.

Impeachment merupakan tuduhan atau dakwaan sehingga pranata impeachment lebih menitikberatkan prosesnya dan tidak mesti berakhir dengan berhenti atau turunnya presiden atau pejabat tinggi negara dari jabatannya. Sedangkan pemakzulan lebih berarti turunnya, berhentinya atau dipecatnya presiden atau pejabat tinggi negara dari jabatannya.

Secara historis, impeachment berasal dari abad ke-14 di Inggris. Parlemen menggunakan lembaga impeachment untuk memproses pejabat-pejabat tinggi dan individu-individu yang amat powerful, yang terkait dalam kasus korupsi, atau hal-hal lain yang bukan merupakan kewenangan pengadilan biasa.

Dalam Black's Law Dictionary, impeachment didefinisikan sebagai, "A criminal proceeding against a public officer, before a quasi political court, instituted by a written accusation called 'articles of impeachment". ${ }^{17}$ Impeachment diartikan sebagai suatu proses peradilan pidana terhadap seorang pejabat publik yang dilaksanakan di hadapan Senat, disebut dengan quasi political court. Suatu proses impeachment dimulai dengan adanya articles of impeachment, yang berfungsi sama dengan surat dakwaan dari suatu peradilan pidana. Jadi, artikel impeachment adalah satu surat resmi yang berisi tuduhan yang menyebabkan dimulainya suatu proses impeachment.

Impeachment merupakan sinonim dari kata accuse yang berarti mendakwa atau menuduh. Sementara Encyclopedia Britanica menguraikan pengertian impeachment sebagai "a criminal proceeding instituted against a public official by a legislative body". Dengan demikian nyatalah bahwa impeachment berarti proses pendakwaan atas perbuatan menyimpang dari pejabat publik. Pengertian demikian seringkali kurang dipahami, sehingga seolah-olah lembaga 'impeachment' itu identik dengan 'pemakzulan', padahal, proses permintaan pertanggungjawaban yang disebut 'impeachment' itu tidak selalu berakhir

\footnotetext{
15 Abdul Rahman, Impeachment Perspektif Ketatanegaraan Indonesia Dan Ketatanegaraan Islam, Fakultas Syariah dan Hukum UIN Alauddin Makassar.

16 Kementerian Pendidikan Nasional, Kamus Besar Bahasa Indonesia, Edisi Baru (Jakarta: Pusat Bahasa, 2013), 975.

17 Henry Campbell Black, Black's Law Dictionary: Definitions of the Terms and Phrases of American and English Jurisprudence,Ancient and Modern (St. Paul, Minn.:West Group, 1991), hal. 516
} 
dengan tindakan pemberhentian terhadap pejabat yang dimintai pertanggungjawaban.

Proses impeachment presiden Indonesia pada masa sebelum perubahan UUD 1945 sangat bergantung kepada kesepakatan dan aturan yang dibuat oleh Majelis Permusyawaratan Rakyat (MPR). Hal ini dikarenakan MPR merupakan lembaga yang memiliki kedudukan tertinggi dalam susunan ketatanegaraan Republik Indonesia dan dianggap sebagai pelaksana dari kedaulatan rakyat. ${ }^{18}$ Oleh karena itu, Presiden bertanggungjawab kepada MPR sebagai lembaga tertinggi negara dalam bentuk pertanggungjawaban politis dengan sanksi berupa pelepasan jabatan Presiden. Hal ini sesuai dengan aturan Pasal 4 Ketetapan Majelis Permusyawaratan Rakyat Nomor III/MPR/1978 tentang Kedudukan dan Hubungan Tata Kerja Lembaga Tertinggi dengan/atau antara Lembaga-Lembaga Tinggi Negara. TAP MPR tersebut menjelaskan beberapa alasan yang dapat dilakukannya pemberhentian presiden yaitu sebagai berikut:

a. Merupakan permintaan sendiri.

b. Berhalangan tetap.

c. Dengan benar telah melanggar haluan Negara.

Pengaturan mengenai pemberhentian Presiden diatur dalam pasal 7A dan 7B UUD 1945 Pasca Amandemen serta mengacu kepada TAP MPR tersebut. Selain itu dalam Pasal 4, Pasal 7 ayat 2 TAP MPR yang sama mengatur mengenai pengawasan DPR dengan menyampaikan memorandum untuk mengingatkan Presiden jika DPR menganggap presiden telah melanggar haluan Negara.

Dalam hal Presiden tidak memperhatikan memorandum tersebut dalam 3 bulan, DPR dapat mengajukan memorandum yang kedua. Jika dalam 1 bulan memorandum yang kedua juga tidak diperhatikan oleh Presiden, maka DPR dapat meminta MPR mengadakan Sidang Istimewa untuk meminta pertanggungjawaban Presiden. Jika mengacu pada kosntitusi yang pernah digunakan, maka terlihat bahwa tidak ada pengaturan mengenai mekanisme impeachment yang secara tegas di dalam konstitusi baik UUD 1945, Konstitusi RIS, maupun UUDS 1950.

Impeachment dalam pandangan Islam

Berbeda dengan dalam pandangan Islam, dimana istilah ini akan rancu jika diartikan turun dari takhta, kekuasaan, atau jabatan karena dalam ketatanegaraan Islam tidak mengenal "makzul". Tapi lebih dikenal istilah nuzul, manzul, dan tanazul yaitu derivasi dari asal kata kerja nazala

18 Jimly Asshiddiqie, Format Kelembagaan Negara dan Pergeseran Kekuasaan dalam UUD 1945, (FH UII Press: Yogyakarta, 2005), 11. 
yang berarti turun atau jatuh. Istilah lain dalam Islam yang sering dikaitkan dengan pemakzulan/impeachment adalah Bughot. Secara etimologis bughot adalah jamak dari baghi, yaitu orang yang berlebihlebihan atau melakukan kerusakan di muka bumi. Sedangkan secara terminologis, para ulama mendefinisikannya sebagai "kelompok umat Islam yang keluar dari ketaatan pemimpin Islam yang sah dengan suatu alasan, menentang hukumnya melalui kekuataan tentara dan penggunaan senjata. Yang dimaksud keluar dari ketaatan pemimpin Islam yang sah adalah jika mereka tidak menaati perintah imam ketika memerintahkan sesuatu yang benar (hak), seperti perintah membayar zakat, perintah untuk berjihad dan lain-lain. Dan ini hukumnya adalah haram. ${ }^{19}$

Menyebut bughot terhadap seseorang atau suatu kelompok muslim tentu tidak boleh sembarangan, tetapi harus mengacu kepada kriteria yang dapat dikatakan sebagai bughot. Misalnya melakukan pembangkangan atau menentang pemimpin menggunakan kekuatan dengan maksud ingin menjatuhkannya tanpa alasan yang benar. Oleh sebab itu, jika penentangan dilakukan terhadap pemimpin dengan cara dan alasan yang benar, seperti menolak kezaliman, $\mathrm{KKN}$ dan lain-lain maka tidak termasuk bughot.

Lembaga yang paling berhak menentukan keputusan, kalau memang keadaan khalifah telah mengalami perubahan yang bisa mengeluarkannya dari jabatan khilafah adalah Mahkamah Madzalim. Lembaga ini juga yang memiliki wewenang untuk memberhentikan atau memberi peringatan kepadanya.

Hal itu dilakukan kalau terjadi salah satu dari beberapa hal yang menyebabkan diberhentikannya khalifah, sementara dalam hal ini yang berhak memberhentikannya adalah Mahkamah Madzalim. Beberapa hal harus dihilangkan, di mana ia merupakan hal-hal yang harus ditetapkan, dan untuk menetapkannya harus diputuskan di hadapan seorang qadli. Karena Mahkamah Madzalimlah yang berhak memutuskan hilangnya kedzalimankedzaliman tersebut, di mana qadli Madzalimlah yang memiliki wewenang untuk menetapkan kedzaliman serta keputusan terhadapnya, maka Mahkamah Madzalim jugalah yang berhak menentukan keputusan apakah salah satu keadaan di atas terjadi, atau tidak. Termasuk dialah yang berhak menentukan pemberhentian khalifah. ${ }^{20}$

\footnotetext{
${ }^{19}$ Abdul Rahman, Impeachment Perspektif Ketatanegaraan Indonesia Dan Ketatanegaraan Islam, Fakultas Syariah dan Hukum UIN Alauddin Makassar.

${ }^{20}$ Ibid.,
} 
Hanya saja, kalau khalifah mengalami salah satu keadaan ini, lalu dia mengundurkan diri, maka masalahnya selesai. Sedangkan kalau kaum muslimin berpendapat, bahwa dia wajib diberhentikan karena keadaan itu telah terjadi maka keputusannya harus dikembalikan kepada qadli. Berdasarkan firman Allah SWT.: "Jika kalian berselisih dalam satu hal, maka kembalikanlah hal itu kepada Allah dan Rasul-Nya." Yaitu, kalau kalian berselisih dengan pemimpin kalian, di mana perselisihan ini merupakan perselisihan antara umat dengan pemimpin, maka mereka harus mengembalikannya kepada Allah dan Rasul-Nya itu berarti mereka harus mengembalikannya kepada qadli, yaitu Mahkamah Madzalim.

Sekalipun umat yang mengangkat khalifah dan membai'atnya, namun umat tetap tidak memiliki wewenang untuk memberhentikan khalifah, selama akad bai'at kepadanya dilaksanakan secara sempurna berdasarkan ketentuan syara'. Hal itu karena banyaknya hadits shahih yang mewajibkan ketaatan kepada khalifah, sekalipun terus-menerus malaksanakan kemunkaran, bertindak dzalim, dan memakan hak-hak rakyat. Selama tidak memerintah berbuat maksiat dan tidak jelas-jelas kufur. Dari Ibnu Abbas berkata: "Rasulullah Saw. bersabda: "Siapa saja yang melihat sesuatu (yang tidak disetujuinya) dari amirnya hendaknya bersabar. Karena siapa saja yang memisahkan diri dari jama'ah sejengkal saja kemudian mati, maka matinya (seperti) mati jahiliyah."11

Kata amir (pemimpin) di dalam hadits ini maknanya umum, yang meliputi khalifah, karena khalifah merupakan amirul mukminin. Dari Abu Hurairah dari Nabi Saw. bersabda:

"Dahulu, Bani Isra'il dipimpin dan dipelihara urusannya oleh para nabi. Setiap kali seorang nabi meninggal, digantikan oleh nabi yang lain. Sesungguhnya tidak akan ada nabi sesudahku. (Tetapi) nanti akan ada banyak khalifah." Para sahabat bertanya: "Apakah yang engkau perintahkan kepada kami?" Beliau menjawab: "Penuhilah bai'at yang pertama dan yang pertama itu saja. Berikanlah kepada mereka haknya, karena Allah nanti akan menuntut pertanggungjawaban mereka tentang rakyat yang dibebankan urusannya kepada mereka."

Imam Muslim pernah meriwayatkan bahwa Salamah Bin Yazid Al Ja'fie bertanya kepada Rasulullah Saw. lalu berkata: "Wahai nabi Allah, kalau ada pemimpin-pemimpin yang memimpin kami, lalu mereka meminta kepada kami hak mereka, namun mereka melarang kami meminta hak kami, maka apa yang engkau perintahkan kepada kami?"

21 Ibid., 
Beliau tidak menghiraukannya, lalu dia bertanya lagi dan beliau juga tidak menghiraukan lagi, kemudian dia bertanya untuk yang kedua atau yang ketiga kalinya, lalu (tangannya) ditarik oleh Asy'ats Bin Qais. Beliau kemudian menjawab:

"Dengar dan ta'atilah, sebab mereka wajib (mempertanggungjawabkan apa yang mereka pikul, sedangkan kalian wajib mempertanggungjawabkan apa yang kalian pikul."

Dari Auf Bin Malik yang berkata:

"Aku mendengar Rasulullah Saw. bersabda: "Sebaik-baik pemimpin kalian adalah mereka yang kalian cintai dan mereka pun mencintai kalian; mereka mendo'akan kalian dan kalian pun mendo'akan mereka. Seburuk-buruk pemimpin kalian ialah mereka yang kalian benci dan mereka pun membenci kalian; kalian melaknat mereka dan mereka pun melaknat kalian."Ditanyakan kepada Rasulullah: "Wahai Rasulullah, tidakkah kita perangi saja mereka itu?" Beliau menjawab: "Jangan, selama mereka masih menegakkan shalat (hukum Islam) di tengahtengah kamu sekalin. Ingatlah, siapa saja yang diperintah oleh seorang penguasa, lalu ia melaksanakan suatu kemaksiatan kepada Allah, maka hendaknya dia membencinya yang merupakan kemaksiatan kepada Allah saja. Dan janganlah sekali-kali melepaskan tangannya dari ketaatan kepadanya."

Dari Hudzaifah Bin Al Yaman bahwa Rasulullah Saw. bersabda:

"Nanti akan datang setelahku, para imam yang mempergunakan petunjuk bukan petunjukku, dan mengikuti sunnah bukan sunahku. Dan di tengah-tengah kalian akan ada orang-orang yang hatinya seperti hati syetan yang berada di dalam tubuh manusia." Aku bertanya: "Bagaimana yang harus aku lakukan, wahai Rasulullah kalau hal itu aku temui." Beliau menjawab: "Engkau dengar dan taati, sekalipun dia memukul punggungmu dan mengambil hartamu, maka dengar dan taatilah."

Dari Abi Dzar bahwa Rasulullah Saw. pernah bertanya (kepadanya): 
"Wahai Abu Dzar, bagaimana kalau kamu mendapatkan pemimpin yang mengambil banyak (hak) darimu dalam pembagian fai' ini?" Dia menjawab: "Demi Dzat yang mengutusmu dengan haq, aku akan menghunus pedangku ini lalu aku letakkan di atas pundaknya. Dan aku akan tebas hingga dia (berubah) sepertimu (baik)." Beliau bersabda: "Bukankah aku pernah tunjukkan sesuatu yang lebih baik untuk kamu lakukan daripada hal itu?, sebaiknya kamu bersabar hingga kamu bisa sepertiku."

Hadits-hadits ini semua menjelaskan bahwa seorang khalifah melaksanakan sesuatu yang semestinya dia diberhentikan. Namun justru Rasulullah memerintahkan taat kepadanya serta sabar terhadap kedzalimannya. Semuanya ini menunjukkan bahwa umat tidak berhak untuk memberhentikan khalifah. Di samping itu, Rasulullah Saw. pernah menolak pelepasan bai'at orang Arab Badui. Dari Jabir Bin Abdullah ra. berkata bahwa ada orang Arab Badui telah membai'at Rasulullah Saw. suatu ketika ia menderita sakit, kemudian berkata: "Kembalikanlah bai'atku padaku. "Ternyata beliau Saw. menolaknya. Lalu dia datang dan berkata: "Kembalikanlah bai'atku kepadaku." Beliau tetap menolak, kemudian orang itu pergi. Lantas beliau bersabda: "Madinah ini seperi tungku (tukang pandai besi), bisa menghilangkan debudebu yang kotor dan membikin cemerlang yang baik."

Semuanya ini menunjukkan bahwa kalau bai'at telah terjadi, maka bai'at tersebut mengikat kedua orang yang membai'at. Hal ini berarti, tidak ada hak bagi mereka untuk memberhentikan khalifah, karena mereka tidak berhak untuk melepaskan bai'atnya. Dan tidak bisa dikatakan, bahwa orang Badui tersebut tidak dihiraukan oleh Rasulullah karena dia ingin melepaskan bai'at dalam rangka keluar dari Islam, bukan keluar dari ketaatan kepada kepala negara. Tidak bisa dikatakan demikian, karena kalau itu yang dimaksud niscaya perlakuan yang diberikan Rasulullah adalah perlakuan terhadap orangorang murtad, dan niscaya ia telah dibunuh oleh Rasulullah, karena orang murtad harus dibunuh. Juga karena bai'at tersebut bukan bai'at untuk masuk Islam, tetapi merupakan bai'at untuk taat kepada khalifah, maka sebenarnya orang tersebut adalah ingin melepaskan ketaatan, bukan untuk melepaskan Islam. Karena kaum muslimin tidak boleh untuk menarik bai'at mereka, maka mereka tidak berhak untuk memberhentikan khalifah. Hanya saja syara' telah menjelaskan kapan khalifah berhenti dengan sendirinya, sekalipun tidak diberhentikan, termasuk kapan dia harus diberhentikan. Begitu juga semuanya ini tidak bisa diartikan, bahwa pemberhentian khalifah adalah hak umat. 
a. Boleh, mengadukan prilaku pejabat tinggi negara dengan etika politik "budi luhur," dengan asas praduga tak bersalah, seperti laporan rakyat Kufah pada khalifah Umar.

b. Khalifah boleh mema'zulkan sementara waktu, pejabat yang bermasalah, dan mengangkatnya kembali setelah kasusnya tuntas. Khalifah Umar mengatakan, aku hanya memberhentikan pejabatku yang tidak memenuhi kriteria dan melakukan tindakan pengkhianatan.

c. Khalifah tidak boleh serta merta menerima laporan pihak lain, sebelum menelusuri fakta yang sesungguhnya (tabayyun) oleh tim khusus yang ditunjuk, saat itu ketua Timnya adalah Muhammad bin Maslamah, asli orang Irak.

d. Dalam sejarah kepemimpinan; antara pemimpin dan yang dipimpin tidak selalu seiring-sejalan. Ini sunnatullah, selalu ada variatif (berlainan) bahkan sampai kontradiktif (berbeda).

e. Tabiat politik dari dulu cenderung abu-abu, karena itu politik disebut dengan siyasah;semacam ada udang dibalik batu. Pada mulanya Sa'ad tersangkut satu kasus, namun Aba Sa'dah menuduhnya dengan pasal berlapis, terkait dengan pribadi Sa'ad (tidak toleran terhadap prajurit), terkait dengan amanah (tidak sama dalam membagi harta) dan terkait dengan supremasi hukum (tidak adil dalam memutuskan perkara)

f. Cross-check (tabayyun); mencocokkan kembali benar-tidaknya berita dengan cara menanyakan langsung kepada orangnya, adalah kemestian dalam adab mengambil keputusan. Sa'ad diminta menghadap dari Irak datang ke ibukota Madinah.

g. Posisi dan kedudukan masjid dalam sejarah kekuasaan, memegang peranan penting, sehingga pasal penyimpangan dalam memimpin sholat berjama'ah bisa mema'zulkan pejabat tinggi.

h. Jama'ah masjid punya suara dan hak yang sama dalam menilai kinerja pemerintahan, bahkan punya suara/hak yang khusus/istimewa, seperti ditunjukan oleh kisah ini.

i. Imam negara dan Imam Sholat; tidak boleh dipisahkan. Pejabat negara sejatinya adalah ahli masjid dan punya kepedulian terhadap jama'ah masjid.

\section{Penanganan Covid-19 di Indonesia}

Ketika Presiden Jokowi mengumumkan langkah-langkah pengendalian penyebaran Covid-19 yang dianggap ahli kesehatan dinilai lamban, saat itu presiden Jokowi menyampaikan dan memerintahkan kepala daerah mulai Provinsi hingga kabupaten dan kota menetapkan penyebaran Covid-19 di wilayahnya dengan berkonsultasi dengan Badan 
Nasional Penanggulangan Bencana atau biasa disebut dengan BNPB. Pernyataan yang dikeluarkan presiden tersebut kemudian disusul dengan penetapan Indonesia dalam status bencana nasional Non alam Covid-19. Hal tersebut dikarenakan terjadinya peningkatan yang begitu tajam pada kasus Covid-19 di Indonesia dalam beberapa hari terakhir.

Kemudian presiden menginstruksikan kepada seluruh rakyat Indonesia agar kegiatan belajar, bekerja, maupun beribadah supaya dilakukan di rumah. Serta menunda segala aktivitas yang berkaitan dengan pengumpulan masa yang banyak. Dalam hal ini juga dilakukan tes Covid-19 serta pengobatan yang dilakukan semaksimal mungkin. ${ }^{22}$

\section{Analisis Terhadap Pandemi Virus Desease Covid-19 sebagai alasan Impeachment Presiden di Indonesia.}

Virus Desease Covid-19 yang terjadi belakangan ini hingga sekarang masih berlanjut adanya, tidak hanya di Indonesia saja, tetapi juga di negara lain. Pemerintah di Indonesia sejak awal mula ditemukan kasus Covid-19, telah melakukan upaya-upaya guna menekan lajur penularan virus. Melalui instruksi yang diberikan oleh presiden Jokowi kepada seluruh jajaran kabinetnya hingga kepala daerah agar lebih mengutamakan kepada percepatan penanganan Virus Desease Covid-19.

Hal tersebut menunjukkan bahwa presiden sebagai kepala negara serta kepala pemerintahan telah melakukan upaya-upaya dalam percepatan penanganan Virus Desease Covid-19 di Indonesia. Oleh karenanya sesuai pasal 7A UUD 1945 amandemen keempat yang menyatakan "Presiden dan wakil presiden dapat diberhentikan dalam masa jabatannya oleh Majelis Permusyawaratan Rakyat atas usul Dewan Perwakilan Rakyat baik apabila terbukti telah melakukan pelanggaran hukum berupa penghianatan terhadap negara, korupsi, penyuapan, tindak pidana berat lainnya, atau perbuatan tercela maupun apabila terbukti tidak lagi memenuhi syarat sebagai Presiden dan/atau wakil presiden". Presiden tidak dapat di Impeachment menurut amanat undang-undang, karena dalam hal ini presiden telah melakukan upayaupaya dalam percepatan penanganan Virus Covid-19 di Indonesia. Oleh karenanya Pandemi Covid-19 ini tidak dapat dijadikan alasan penjatuhan Impeachment seorang Presiden.

\footnotetext{
22 Zahrotunnimah, Langkah Taktis Pemerintah Daerah Dalam Pencegahan Penyebaran Virus Covid -19 di Indonesia, (Jurnal UIN Syarif Hidayatullah: Jakarta, 2020).
} 


\section{Kesimpulan.}

Berdasarkan uraian yang dijelaskan penulis diatas terdapat beberapa kesimpulan. Pertama mengenai peraturan Impeachment di Indonesia Pasca Amandemen UUD 1945 yang telah diatur di dalam Pasal 7A dan 7B UUD 1945 serta TAP MPR No III/MPR/1978 mengenai faktor-faktor dalam penjatuhan Impeachment yang merupakan kewenangan MPR. Tetapi peraturan mengenai Impeachment tersebut masih dianggap belum secara tegas konsekuensi hukumnya, sehingga perlunya pembenahan di dalam pengaturan tersebut. Kedua mengenai upaya-upaya yang dilakukan pemerintah yaitu presiden dalam hal percepatan penanganan Virus Desease Covid-19. Ketiga, adanya Pandemi Virus Desease Covid-19 ini tidak dapat dijadikan suatu alasan untuk penjatuhan Impeachmen Presiden, karena Presiden telah melakukan upaya semaksimal mungkin dalam penanganan Virus tersebut. 


\section{DAFTAR PUSTAKA}

Asshiddiqie Jimly. 1994. Gagasan Kedaulatan Rakyat Dalam Konstitusi dan Pelaksanaannya di Indonesia. Jakarta: PT. Ichtiar Baru Van Hoeve.

Asshiddiqie Jimly. 2005. Format Kelembagaan Negara dan Pergeseran Kekuasaan dalam UUD 1945. FH UII Press: Yogyakarta.

Kusuma. 2011. Sistem Pemerintahan "Pendiri Negara" Versus Sistem Presidensia "Orde Reformasi". Badan Penerbit Fakultas Hukum Universitas Indonesia. Depok.

Martosoewignjo Sri Soemantri. 2016. Konstitusi Indonesia: Prosedur dan Sistem Perubahannya Sebelum dan Sesudah UUD 1945. Perubahan. Rosdakarya: Bandung.

Soehino. 1993. Hukum Tata Negara: Sistem Pemerintahan Negara. Penerbit Liberty.

Rahman Abdul. Universitas Islam Negeri Alaudin Makasar. Impeachment Dalam UUD 1945 Pasca Amandemen (Annalisis Terbadap Proses Hukum Vis-a-Vis Proses Politik.

Zhrotunnimah. 2020. Langkah Taktis Pemerintah Daerah Dalam Pencegahan Penyebaran Virus Covid-19 di Indonesia. Jurnal UIN Syarif Hidayatullah. Jakarta. 